This is a pre-copyedited, author-produced PDF of an article accepted for publication in Teaching Mathematics and its Applications following peer review. The version of record Eabhnat Ni Fhloinn, Brien C. Nolan, Giulio Hoehne Candido \& Shannon M. Guerrero (2018) Pre-service versus in-service mathematics teachers' opinions of mathematics reform in post-primary schools in Ireland, Irish Educational

Studies, 37:4, 431-452, DOI: 10.1080/03323315.2018.1512884

is available online at

https://www.tandfonline.com/doi/full/10.1080/03323315.2018.1512884

\title{
Pre-service versus in-service mathematics teachers' opinions of mathematics reform in post-primary schools in Ireland
}

\author{
Eabhnat Ní Fhloinn ${ }^{1}$, Brien C. Nolan ${ }^{1}$, Giulio Candido ${ }^{2}$ and Shannon M. \\ Guerrero $^{3}$
}

${ }^{1}$ School of Mathematical Sciences, Dublin City University, Dublin, Ireland

${ }^{2}$ Department of Engineering and General Studies, Dublin Institute of Technology,

Dublin, Ireland

${ }^{3}$ Department of Mathematics and Statistics, Northern Arizona University, Flagstaff, Arizona

Eabhnat.nifhloinn@dcu.ie 


\title{
Pre-service versus in-service mathematics teachers' opinions of mathematics reform in post-primary schools in Ireland
}

\begin{abstract}
A new approach to the teaching and learning of mathematics has been introduced on a phased basis in post-primary education in Ireland. As part of the OECD PISA 2012, a survey was undertaken of in-service mathematics teachers in Ireland, with the aim of gathering data on the opinions of teachers about this reform. Here, a modified version of the survey was distributed to pre-service teachers immediately before and after a four-month teaching placement to ascertain if there were differences in the views expressed by pre-service and in-service teachers in relation to the teaching and learning of mathematics, and also if there were differences expressed by the pre-service teachers before and after their placement in post-primary schools. Analysis of the results showed considerable levels of agreement between all groups, with some exceptions in relation to confidence in teaching the reformed curriculum, emphasis on various teaching and learning activities, and usage of ICT in the classroom.
\end{abstract}

Keywords: pre-service teachers; in-service teachers; mathematics reform; post-primary mathematics; teaching placement

\section{Introduction}

In September 2008, a new approach to the teaching and learning of mathematics at postprimary level in Ireland was introduced to a group of 24 "pilot" schools (Cosgrove et al. 2012, 8), and was known as "Project Maths". From September 2010, it was introduced on a nationwide, phased basis, with changes implemented simultaneously at two stages within post-primary: first year (the start of Junior Cycle) and fifth year (the start of Senior Cycle). This reform incorporated changes to the syllabi, examinations and recommended teaching approaches, and was motivated by a number of factors, including the fact that a reform of the full post-primary mathematics curriculum last 
took place in the 1960s; a revised primary school mathematics curriculum was phased in from 1999; a number of studies had highlighted concerns about the mathematical skills of Irish students, both in secondary school and higher education; and a range of more recent developments in mathematics education research had not been considered in the existing curriculum (NCCA 2005, 3-7).

The need for reform of the teaching and learning of mathematics is not unique to Ireland, but international in scope (Adler 2000, 205; Conway and Sloane 2005; Sowder 2007, 159). Lubienski (2011) draws parallels between the reform in Ireland and that led by the National Council of Teachers of Mathematics in the USA, while noting that the educational context was quite different. Pivotal to any such reform are the mathematics teachers themselves, as "unless the classroom teacher understands and is committed to standards-based reform and knows how to make it happen, the dream will not be realized" (AFT 2002, 2, cited in Sowder 2007, 157).

In association with Ireland's participation in the OECD Programme for International Student Assessment (PISA) 2012, a survey was undertaken in Ireland of in-service mathematics teachers (i.e. qualified teachers working in schools), the full details of which are reported by Cosgrove et al (2012). They list four main aims of their survey, of which one is particularly relevant to the work reported here: namely to gather empirical and qualitative data on the opinions of a nationally representative sample of teachers about the implementation of Project Maths, and to undertake a comparison between the responses of teachers in pilot schools (who have spent two years longer teaching Project Maths than their counterparts in other schools) and teachers in other schools.

Given that change of this nature for teachers is "a process rather than an event" (Sowder 2007, 194), it is of particular interest to also investigate the opinions of pre- 
service mathematics teachers about this reform, and that is what we have undertaken to do in this study. Bearing in mind the words of Philipp (2007), who stated that "researchers have found that for some teachers, beliefs change before practice, whereas for others, changes in practice preceded changes in belief'" (Philipp 2007, 309), we decided to conduct the survey both before and after an extended teaching placement in a school setting, so that any potential impact of this upon the pre-service teachers' opinions can be observed. For questions relating to the practice of teaching mathematics, the responses of pre-service teachers prior to their teaching placement are understood to be intentions, whereas after their teaching placement, they are read as experiences. A number of research questions are thus addressed in this paper:

- Are there differences in the views expressed by pre-service and in-service teachers in relation to mathematics reform in the shape of Project Maths?

- Are there differences in the views expressed by pre-service and in-service teachers in relation to general opinions about the teaching and learning of mathematics?

- Are there differences in the views expressed by pre-service teachers before and after their teaching placement on any of the above issues?

\section{Background}

Ireland has a single, national curriculum for school mathematics, which determines both what is taught and the assessment (DES 2015). An overview is now provided of postprimary education in Ireland, as well as the Project Maths reform, to set the context for the survey undertaken. 


\section{Secondary School Education in Ireland}

In Ireland, pupils begin secondary school aged approximately 13 and spend between five and six years there. After three years, they take a state examination known as the Junior Certificate; after this, some pupils do "Transition Year", which offers time for more non-academic pursuits; and then pupils follow a two-year programme before sitting a high-stakes state examination commonly known as the "Leaving Certificate" (DES 2004, 13). Their results in this determine admission to higher education, based on an overall score calculated from each student's best six grades (CAO 2014, 19). Mathematics is taken by almost all students throughout post-primary, and is offered at three levels: Higher, Ordinary and Foundation (DES 2004, 14).

\section{Project Maths}

Project Maths was designed by the National Council for Curriculum and Assessment (NCCA) and implemented by the Department of Education and Skills in Ireland, with the aim of improving the mathematical literacy of post-primary students. The curriculum is divided into five strands: Statistics and Probability; Geometry and Trigonometry; Number; Algebra; and Functions. These strands were introduced to schools on a phased basis: Strands 1 and 2 being introduced in the first year of the rollout, followed by Strands 3 and 4 in the second year and Strand 5 in the third. This meant that the appropriate versions were introduced simultaneously for First Year students (the first year of Junior Cycle) and Fifth Year students (the first year of Senior Cycle). Thus, the first nationwide Leaving Certificate mathematics examinations based fully on Project Maths took place in June 2014, and the corresponding Junior Certificate examinations in June 2015. It was not until 2017 that the first cohort of post-primary students to experience only Project Maths completed their schooling. Reform efforts also focussed on the teaching of mathematics, with the recommendation that it move to 
a more student-centred approach. Professional development workshops focusing on classroom practice and evening courses on mathematics content were run to support teachers throughout the process (Cosgrove et al 2012). They were also supported in adopting ICT in the classroom as more than just a visual aid: this was seen as an important part of Project Maths (NCCA 2012).

The results below should be understood in the context of this transition period. The Project Maths reform was in part motivated by concerns about the dominance of traditional didactical approaches in Irish mathematics classrooms as described (for example) in Lyons et al. (2003). Recent research has shown some evidence of a gradual move from this. In 2013, an NCCA-commissioned report noted that "(a)lthough there is evidence that more traditional approaches to teaching mathematics remain widespread,...there are numerous examples of promising practice in transforming the way that mathematics is delivered in the classroom" (Jeffes et al. 2013, 71). If we fastforward to 2017, we find that "Project Maths has had a significant impact on approaches to teaching and learning mathematics in schools" (Shiel and Kelleher 2017, 193) and that there is evidence to "suggest that considerable progress has been made in introducing more meaning-orientated approaches" (194). It is worth noting that Irish post-primary students' general experience is "highly teacher-led", and that this feature becomes more dominant in examination years (Smyth 2016, 167 et seq). Other important aspects of the outcomes of Project Maths have attracted the attention of researchers, for example the impact on mathematics in higher education (Treacy and Faulkner 2015; Prendergast et al. 2017), and changes to the time spent on mathematics in post-primary classrooms (Prendergast and O’Meara 2017).

\section{Pre-service and In-service Teachers}

A number of studies have been undertaken looking at differences between pre-service 
and in-service teachers, in terms of attitudes, classroom practices, pedagogical content knowledge, approaches to assessment and usage of technology, among other characteristics, across a range of subject disciplines. Some such studies focused on the transition from pre-service to early years of in-service (Ensor 2001; Russell et al. 2003; Steele 2001); others compared pre-service and in-service teachers (Bos et al. 2001; Bean and Patel Stevens 2002; Murphy, Delli and Edwards 2004; Shim, Young and Paolucci 2010; Sullivan-Watts et al. 2013); while more considered the impact of a teaching placement upon pre-service teachers (Bullock 2004; Swars et al. 2007; Ng, Nicholas and Williams 2010; Bjerke et al. 2013). There are recurrent themes running throughout these works that are relevant to our study, such as the struggle to maintain what individual pre-service teachers value in their (primarily) theoretical teachereducation experiences in university when confronted with classroom realities. Another key theme is the role of school culture(s) in influencing the beliefs and practices of preservice teachers. Cherubini (2009) interprets this struggle and the associated notions of socialisation and acculturation in terms of a conflict between "post-industrial" conceptions held by new teachers, which emphasise individuality and self-agency, and the "industrial" nature of school systems. Our research methodology does not afford the opportunity to address the influence of school culture and professional socialisation on the pre-service teachers' opinions. We will however attempt to address the themes mentioned above by considering the alignment of the opinions of in-service teachers, and those of pre-service teachers both before and after school placement: in relation to the domains covered in the survey, do pre-service teachers hold opinions that are different to those of in-service teachers, and does undertaking a period of school placement change these opinions? 
Pre-service versus in-service teachers

Steele (2001) posed the question: "Did pre-service teachers sustain their new conceptions about mathematics and mathematics teaching and learning and implement a reform-based approach to mathematics teaching when they became teachers?" (142). Her four-year longitudinal study following four new teachers in the U.S. revealed a number of challenges in the workplace (such as institutional and societal pressures) which interfered with early-years teachers sustaining these new conceptions about mathematics, although some teachers were more immune than others. Similarly, Ensor (2001) tracked seven mathematics teachers in South Africa over a two-year period, during their final pre-service year and first in-service year, focusing on the "apparent inconsistency between what is offered in teacher education courses, and the manner in which beginning teachers perform in classrooms" (317). She argues that the effects of teacher education were "not 'washed out'...but transformed" (316), with, for example, one beginning teacher using a number of tasks in the classroom that had been introduced to her in teacher education courses, while feeling unqualified to produce her own analogous resources. Ensor suggests that this university module influenced the teacher's "professional argot" (vocabulary used to describe best practice in teaching) more than it did her classroom practice. More generally, Allen (2009) found that, while as pre-service teachers, students valued both the training they received in university and while on teaching placement, once they graduated to in-service teachers they placed higher value on practice observed in schools.

Swars et al (2007) investigated the mathematical beliefs and content knowledge of a group of pre-service elementary school teachers in the U.S. over the period of two courses, during which time the teachers undertook a number of teaching placements. Each teacher completed two surveys on four different occasions spaced out over this 
time. The authors concluded that the school placements did not negatively impact upon their observed newly-acquired beliefs which were "more consistent with a reform perspective”. Murphy et al (2004) conducted a study comparing beliefs about what constitutes "good teaching" between second-grade students, pre-service and in-service teachers in the U.S. Their findings were that, while there were clear distinctions between the second-grade students and the in-service teachers, the pre-service teachers "seemed to possess beliefs that mirrored both the second graders and in-service teachers" (69).

Pre-service teachers before and after teaching placement

Bjerke et al (2013) distributed a questionnaire to 202 Norwegian pre-service mathematics teachers in their first year, before their first teaching placement. They then had 31 of these students complete a survey after six days on teaching placement, and a further 137 after four weeks on placement. They concluded that, although the preservice teachers did reflect upon the difficulty of "translating theory into practice" while teaching, it was felt that they had not grasped the point of much of what had been covered with them in university prior to their placement. Ng, Nicholas and Williams (2010) tracked 37 pre-service students in Australia from before their first placement throughout their year-long graduate programme to become teachers. They found that pre-service teachers' beliefs about "good teaching" evolved over the course of a number of teaching placements, particularly in relation to student achievement and the notion of being in control. They observed that "their beliefs about good teaching evolved from believing teachers have "expert control" to a focus on preventing loss of "personal control"...(after the first teaching placement) and back to a belief about more studentcentred control" (287). In addition, a number of beliefs remained constant, such as the need to manage student learning, or the personal characteristics of a good teacher (kind, 
caring, understanding and so on). In a study of the professional beliefs of pre- and post-placement student teachers, Gleeson et al. (2015) note a "stark contrast" between the student teachers' pre-placement preferences and their post-placement assessment of the feasibility of curriculum reform options in relation to Junior Cycle education in Ireland. The authors highlight the important role of the socialisation of apprentice teachers, and suggest that the students "were heavily influenced by the prevailing culture of teachers and schools" (450).

\section{Methodology}

\section{Research subjects}

The pre-service teachers involved in this study were a single cohort of students in their third year in B.Sc. in Science Education in Dublin City University, Ireland. This is a four-year concurrent science and mathematics teacher education programme in which students specialise in two subjects out of Physics, Chemistry and Mathematics. During the second semester of their third year, students undertook a full-time teaching placement in a school, during which they had responsibility for the preparation, delivery and assessment of several class-groups in their subject areas. These students had previously completed a two-week teaching placement in a different school during second year, as well as micro-teaching during first year, but the third-year placement was an opportunity for them to function as part of a teaching staff in a school for several months. They were assessed by supervisors from Dublin City University throughout their placement, and worked under the direct supervision of teachers in their schools. There were 36 students in the class, who were asked to complete a survey on two separate occasions, once before their placement, and once afterwards. This gave us two linked cohorts to consider, referred to below as Pre-Service $1(\mathrm{~N}=25)$ and Pre-Service 2 
$(\mathrm{N}=19)$. We note that 14 of these students completed both surveys, and we will refer to this sub-cohort as Pre-Service-Dual. In some instances, it is of particular interest to study the responses of the Pre-Service-Dual group in isolation, as it allows us to consider a paired pre- and post-placement response. The responses of the pre-service teachers were compared and contrasted with those of the in-service teachers from Cosgrave et al (2012). This was a far larger group $(\mathrm{N}=1321)$, comprised of mathematics teachers in a random, nationally representative, sampling of schools in Ireland that participated in PISA 2012. (See (Cosgrave et al 2012, 17-18) for details, including demographic and school-related characteristics of these teachers.)

\section{Research instrument}

The pre-service teachers completed a 30-question survey consisting of a mixture of Likert-scale and open-ended questions. Of these, the middle 17 questions were taken from the teacher survey undertaken as part of PISA 2012 (Cosgrove et al 2012). In the original survey, all 17 of these are closed-response multiple-choice items. However, for two of these questions, we also requested that the pre-service teachers comment on their responses. These questions related to the use of ICT in the classroom, and to the perceived challenges of implementing the new curriculum. The increased use of ICT as a means of enhancing understanding is a central aim of Project Maths and one might expect the pre-service teachers (as 'digital natives') to have an enhanced capacity for this. As teacher educators, we were also keen to develop more nuanced insights into their perceptions of the challenges of the new curriculum.

Three of the 17 questions needed to be slightly modified to suit the pre-service cohort, who would not yet be in a position to comment upon aspects such as reactions of parents or pupils, for example. The first eight questions addressed pre-service teachers' attitudes to Project Maths, and the last five their opinions on their teacher education 
programme vis-à-vis preparation for teaching mathematics. These questions do not form part of the present study. The 17 questions relevant to this study can be summarised under seven headings: fixed view of mathematics; constructivist/applied view of mathematics; classroom activity; differentiated teaching practices; usage of ICT resources; confidence levels in teaching aspects of Project Maths; and perceived challenges in the implementation of Project Maths.

The survey was issued in Spring 2015 the week before the pre-service teachers began their teaching placement and then again in their final week in the school. The first survey was a paper-based exercise during class-time, whereas the second survey was conducted online, as the pre-service teachers were still off-campus on placement.

The descriptive analysis undertaken consisted of two different approaches: firstly, to compare the responses of the In-Service teacher group separately against the Pre-Service 1 and Pre-Service 2 cohorts; and secondly to compare the paired pre- and post-responses within the Pre-Service-Dual sub-cohort. As there are a large number of separate items within the 17 questions studied, not all of these are discussed below; full results are reported within the tables, and then those of particular note are explored in more detail.

\section{Limitations of the study}

There are a number of limitations in this study. The relatively small size of the PreService 1 and 2 cohorts (and sub-cohort Pre-Service-Dual), and the much greater size of the In-Service cohort $(\mathrm{N}=1231)$, must be borne in mind when considering the generality of the results and conclusions discussed below. The results given are descriptive only in nature, as it would not be possible to confirm that the students who answered the survey represented a random sample of the population and this, combined with the small sample sizes, would call statistical testing into question. 


\section{Results}

We present our results to the 17 survey questions following a thematic structure based around the seven themes mentioned above. We must first note the following in relation to the first two themes (fixed view of mathematics, and constructivist/applied view of mathematics):

Initially, pre-service teachers were asked to indicate their level of agreement (on a four-point Likert scale from Strongly Disagree to Strongly Agree) with a series of twelve statements about the general nature of mathematics and mathematics teaching and learning. In the work of Cosgrave et al (2012), these questions were designed so that the first six reflected a more "fixed" view of mathematics, while the second six a “constructivist/applied" view of mathematics (34). These questions were used by Cosgrove et al to form two scales, using principal component analysis. However, it was found that the first scale (reflecting a "fixed" view) had a low reliability, generating Cronbach's alpha value of 0.42 (35), while the other scale had an acceptable one of $\alpha=0.69$ (78). It should be borne in mind that there are only six questions in each scale, which is on the low side for principal component analysis (O'Rourke, Psych and Hatcher 2013, 12-13). Therefore, following Cosgrave et al (2012), we shall not consider these questions in terms of two scales, but rather focus on any individual questions that yielded interesting results. 


\section{Fixed view of mathematics}

Table 1 indicates the levels of agreement/disagreement with the first six statements ${ }^{1}$.

Although these were posed as a four-point Likert scale, the responses have been

collapsed into binary agree/disagree categories.

Table 1. Teachers' levels of agreement/disagreement with six statements about mathematics and T\&L of mathematics. Pre-service 1 refers to pre-service teachers before their long teaching placement; Pre-service 2 refers to afterwards. ("In-service" $\mathrm{N}$ $=1321$, "Pre-service 1 " $\mathrm{N}=25$, "Pre-service $2 " \mathrm{~N}=19$.)

\begin{tabular}{|c|c|c|c|}
\hline & & $\begin{array}{c}\text { Strongly } \\
\text { Disagree/ } \\
\text { Disagree }\end{array}$ & $\begin{array}{l}\text { Agree/ } \\
\text { Strongly } \\
\text { agree }\end{array}$ \\
\hline \multirow{3}{*}{$\begin{array}{l}\text { Some students have a natural talent for } \\
\text { mathematics and others do not }\end{array}$} & In-service & $12.0 \%$ & $88.0 \%$ \\
\hline & Pre-service 1 & $8.4 \%$ & $91.6 \%$ \\
\hline & Pre-service 2 & $10.0 \%$ & $90.0 \%$ \\
\hline \multirow{3}{*}{$\begin{array}{l}\text { If students are having difficulty, an } \\
\text { effective approach is to give them more } \\
\text { practice by themselves during the class }\end{array}$} & In-service & $42.7 \%$ & $57.3 \%$ \\
\hline & Pre-service 1 & $57.1 \%$ & $42.9 \%$ \\
\hline & Pre-service 2 & $53.0 \%$ & $47.0 \%$ \\
\hline \multirow{3}{*}{$\begin{array}{l}\text { Mathematics is a difficult subject for most } \\
\text { students }\end{array}$} & In-service & $67.0 \%$ & $33.0 \%$ \\
\hline & Pre-service 1 & $41.7 \%$ & $58.3 \%$ \\
\hline & Pre-service 2 & $32.0 \%$ & $69.0 \%$ \\
\hline \multirow{3}{*}{$\begin{array}{l}\text { Few new discoveries in mathematics are } \\
\text { being made }\end{array}$} & In-service & $67.6 \%$ & $32.4 \%$ \\
\hline & Pre-service 1 & $45.4 \%$ & $54.5 \%$ \\
\hline & Pre-service 2 & $68.0 \%$ & $32.0 \%$ \\
\hline \multirow{3}{*}{$\begin{array}{l}\text { Mathematics is primarily an abstract } \\
\text { subject }\end{array}$} & In-service & $81.2 \%$ & $18.8 \%$ \\
\hline & Pre-service 1 & $75.0 \%$ & $25.0 \%$ \\
\hline & Pre-service 2 & $74.0 \%$ & $26.0 \%$ \\
\hline \multirow{3}{*}{$\begin{array}{l}\text { Learning mathematics mainly involves } \\
\text { memorising }\end{array}$} & In-service & $90.1 \%$ & $9.9 \%$ \\
\hline & Pre-service 1 & $91.6 \%$ & $8.4 \%$ \\
\hline & Pre-service 2 & $95 \%$ & $5.0 \%$ \\
\hline
\end{tabular}

It is clear that there is extremely close agreement between the three groups for statements such as "Some students have a natural talent for mathematics and others do

\footnotetext{
${ }^{1}$ In the tables below, we have chosen to quote the results as percentages in each case (i.e. for each cohort). We do this for reasons of consistency, despite the fact that the percentages quoted will on occasion refer to a single student. Each table quotes relevant $\mathrm{N}$ values, so no confusion should arise.
} 
not", with the largest gap being 3.6\% between any two of the three cohorts.

In contrast, there is a noticeable difference in agreement levels with the statement "Mathematics is a difficult subject for most students", with 33\% of in-service teachers agreeing or strongly agreeing with this, compared to $58.3 \%$ and $69 \%$ of preservice teachers (before and after teaching placement, respectively). Another interesting response is given to "Few new discoveries in mathematics are being made", where the numbers of in-service teachers and pre-service teachers after their placement agreeing with this statement are very close, $(32.4 \%$ and $32 \%$ respectively), but far more pre-service teachers before their placement agree with the statement $(54.5 \%)$. In this case, the most pertinent group is the Pre-Service-Dual subcohort, who answered the survey both before and after their placement. Of these, $30 \%$ $(\mathrm{N}=4)$ changed their response from agreement to disagreement, while $8 \%(\mathrm{~N}=1)$ changed from disagreement to agreement. This is an unexpected outcome, but perhaps indicates (acknowledging the low $\mathrm{N}$ values) a degree of uncertainty among the preservice teachers in relation to this statement.

\section{Constructivist/applied view of mathematics}

Full responses to the second series of six questions are shown in Table 2 below. Again, these can be collapsed into two binary categories indicating general agreement/disagreement with the statements. For three statements, the level of agreement across the groups differs by at most $2 \%$. Three of the statements result in more than a ten-percentage-point difference between the two pre-service groups. "More than one representation (picture, concrete material, symbols etc) should be used in teaching a mathematics topic" resulted in a difference of $11 \%$, with more respondents disagreeing with this statement in the Pre-service 2 group; "Solving mathematics problems often involves hypothesizing, estimating, testing and modifying findings" 
showed a difference of $15.8 \%$, where more respondents from Pre-service 1 disagreed with this statement; and "To be good at mathematics at school, it is important for students to understand how mathematics is used in the real world" resulted in a $16 \%$ drop in the level of agreement of the pre-service cohort between the pre-placement and post-placement stages of the survey. It is notable that all three changes are indicative of a decline in the cohort's adherence to a constructivist/applied view of mathematics.

Table 2. Teachers' levels of agreement/disagreement with six other statements about mathematics and T\&L of mathematics. ("In-service" $\mathrm{N}=1321$, "Pre-service 1" $\mathrm{N}=25$, "Pre-service $2 " \mathrm{~N}=19$.)

\begin{tabular}{|c|c|c|c|}
\hline & & $\begin{array}{l}\text { Strongly } \\
\text { Disagree/ } \\
\text { Disagree }\end{array}$ & $\begin{array}{l}\text { Agree/ } \\
\text { Strongly } \\
\text { agree }\end{array}$ \\
\hline \multirow{3}{*}{$\begin{array}{l}\text { There are different ways to solve most } \\
\text { mathematical problems }\end{array}$} & In-service & $3.3 \%$ & $96.7 \%$ \\
\hline & Pre-service 1 & $0.0 \%$ & $100 \%$ \\
\hline & Pre-service 2 & $0.0 \%$ & $100 \%$ \\
\hline \multirow{3}{*}{$\begin{array}{l}\text { More than one representation (picture, } \\
\text { concrete material, symbols etc) should be } \\
\text { used in teaching a mathematics topic }\end{array}$} & In-service & $3.5 \%$ & $96.5 \%$ \\
\hline & Pre-service 1 & $0.0 \%$ & $100 \%$ \\
\hline & Pre-service 2 & $11.0 \%$ & $89.0 \%$ \\
\hline \multirow{3}{*}{$\begin{array}{l}\text { Solving mathematics problems often } \\
\text { involves hypothesizing, estimating, testing } \\
\text { and modifying findings }\end{array}$} & In-service & $11.7 \%$ & $88.3 \%$ \\
\hline & Pre-service 1 & $20.8 \%$ & $79.2 \%$ \\
\hline & Pre-service 2 & $5.0 \%$ & $95.0 \%$ \\
\hline \multirow{3}{*}{$\begin{array}{l}\text { Modelling real-world problems is essential } \\
\text { to teaching mathematics }\end{array}$} & In-service & $12.3 \%$ & $87.7 \%$ \\
\hline & Pre-service 1 & $8.0 \%$ & $92.0 \%$ \\
\hline & Pre-service 2 & $5.0 \%$ & $95.0 \%$ \\
\hline \multirow{3}{*}{$\begin{array}{l}\text { To be good at mathematics at school, it is } \\
\text { important for students to understand how } \\
\text { mathematics is used in the real world }\end{array}$} & In-service & $15.8 \%$ & $84.2 \%$ \\
\hline & Pre-service 1 & $16.0 \%$ & $84.0 \%$ \\
\hline & Pre-service 2 & $32.0 \%$ & $68.0 \%$ \\
\hline \multirow{3}{*}{$\begin{array}{l}\text { A good understanding of mathematics is } \\
\text { important for learning in other subject } \\
\text { areas }\end{array}$} & In-service & $20.1 \%$ & $79.9 \%$ \\
\hline & Pre-service 1 & $20.0 \%$ & $80.0 \%$ \\
\hline & Pre-service 2 & $10.0 \%$ & $90 \%$ \\
\hline
\end{tabular}

However, again a close inspection of the 14 Pre-Service-Dual respondents who answered both surveys showed that only 2 respondents changed their opinions from agreement to disagreement or vice versa in each of these three questions, with one respondent changing his mind on each of these three questions. Again, due to the small sample size in question, it is difficult to comment further on the possible reasons for 
such an outcome.

\section{Classroom activity}

In-service teachers were also asked about the emphasis they place upon various teaching or classroom activities, when working with third-year pupils (Cosgrove et al 2012, 24). (We recall that Irish students sit the Junior Certificate examination at the end of third year, making this the first year in which students participate in state-run examinations in secondary school.) We asked the same question of the pre-service teachers, but did not limit the question to their work with just third-year pupils, as some may have had limited or no experience working with that particular year-group to date. The results are shown in Table 3 below.

Table 3. Emphasis on each teaching/classroom activity in mathematics class. Note: Inservice teachers answered only in relation to 3rd year students. ("In-service" $\mathrm{N}=1321$, “Pre-service 1" $\mathrm{N}=25$, “Pre-service 2 " $\mathrm{N}=19$.)

\begin{tabular}{|l|l|r|r|c|}
\hline & & No/Low & Medium & High \\
\hline \multirow{3}{*}{ Whole class teaching activities } & In-service & $5.4 \%$ & $21.7 \%$ & $72.9 \%$ \\
\cline { 2 - 5 } & Pre-service 1 & $8.0 \%$ & $64.0 \%$ & $24.0 \%$ \\
\cline { 2 - 5 } & Pre-service 2 & $5.0 \%$ & $79.0 \%$ & $16.0 \%$ \\
\hline \multirow{3}{*}{ Individual student learning activities } & In-service & $19.6 \%$ & $38.7 \%$ & $41.7 \%$ \\
\cline { 2 - 5 } & Pre-service 1 & $12.0 \%$ & $56.0 \%$ & $32.0 \%$ \\
\cline { 2 - 5 } & Pre-service 2 & $5.0 \%$ & $53.0 \%$ & $42.0 \%$ \\
\hline \multirow{3}{*}{ Student group learning activities } & In-service & $51.4 \%$ & $34.4 \%$ & $14.1 \%$ \\
\cline { 2 - 5 } & Pre-service 1 & $4.0 \%$ & $60.0 \%$ & $36.0 \%$ \\
\cline { 2 - 5 } & Pre-service 2 & $11.0 \%$ & $63.0 \%$ & $26.0 \%$ \\
\hline \multirow{3}{*}{$\begin{array}{l}\text { Keeping order in classroom } \\
\text { (maintaining discipline) }\end{array}$} & In-service & $12.2 \%$ & $49.9 \%$ & $37.9 \%$ \\
\hline \multirow{3}{*}{$\begin{array}{l}\text { Administrative tasks } \\
\text { (e.g. recording attendance) }\end{array}$} & Pre-service 1 & $0.0 \%$ & $40.0 \%$ & $60.0 \%$ \\
\cline { 2 - 5 } & Pre-service 2 & $11.0 \%$ & $53.0 \%$ & $37.0 \%$ \\
\hline & In-service & $33.0 \%$ & $22.0 \%$ & $45.0 \%$ \\
\cline { 2 - 5 } & Pre-service 1 & $8.0 \%$ & $40.0 \%$ & $52.0 \%$ \\
\cline { 2 - 5 } & Pre-service 2 & $16.0 \%$ & $53.0 \%$ & $32.0 \%$ \\
\hline & In-service & $50.2 \%$ & $21.2 \%$ & $28.6 \%$ \\
\cline { 2 - 5 } & Pre-service 1 & $45.9 \%$ & $20.8 \%$ & $29.2 \%$ \\
\cline { 2 - 5 } & Pre-service 2 & $63.0 \%$ & $26.0 \%$ & $11.0 \%$ \\
\hline
\end{tabular}

There is some variation between the three groups here on a number of questions, which 
is particularly evident in the percentages of each group who placed a high emphasis on various activities.

The most striking difference is the emphasis placed by in-service teachers on "whole class teaching activities" (with 72.9\% ranking this as high emphasis) compared with the responses of the two pre-service groups (with $24 \%$ and $16 \%$ respectively ranking it as high). However, it should be noted here that the majority of pre-service teachers did assign a "medium" emphasis to this area. The other noteworthy difference evident in Table 3 is in relation to the emphasis placed on "student assessment activities", where there is good agreement between in-service teachers and the preservice teachers who have completed their placements, but a greater proportion of the Pre-Service 1 group placed a high emphasis on this activity. A similar pattern can be observed in the responses to the emphasis on "administrative tasks", although the agreement here is between in-service teachers and pre-service teachers before their teaching placement. When only the 14 Pre-Service-Dual respondents are considered, it is worth noting that the percentage of respondents who placed a high emphasis reduced from $64.3 \%$ to $28.6 \%$ in relation to student assessment, and from $35.7 \%$ to $7.1 \%$ in relation to administration.

\section{Usage of differentiated teaching practices}

In-service teachers were asked about their usage of differentiated teaching practices, again in relation to the teaching of third-year pupils only (Cosgrove et al 2012, 41). As before, we asked this question of the pre-service groups, but allowed them to answer without restrictions (i.e. regardless of what year group they were teaching). The results are shown in Table 4. 
Table 4. Frequency with which teachers use differentiated teaching and learning approaches within their mathematics classes. Note: in-service teachers answered in relation to 3rd year students only. ("In-service" $\mathrm{N}=1321$, "Pre-service 1" $\mathrm{N}=25$, "Preservice $2 " \mathrm{~N}=19$.)

\begin{tabular}{|c|c|c|c|}
\hline & & $\begin{array}{l}\text { Never/ } \\
\text { Rarely }\end{array}$ & $\begin{array}{l}\text { Sometimes/ } \\
\text { Often }\end{array}$ \\
\hline \multirow{3}{*}{$\begin{array}{l}\text { I provide different class material or } \\
\text { activities to students of differing ability } \\
\text { levels }\end{array}$} & In-service & $31.0 \%$ & $69.0 \%$ \\
\hline & Pre-service 1 & $16.7 \%$ & $83.3 \%$ \\
\hline & Pre-service 2 & $58.0 \%$ & $42.0 \%$ \\
\hline \multirow{3}{*}{$\begin{array}{l}\text { I get students to work in mixed-ability } \\
\text { pairs or small mixed-ability groups }\end{array}$} & In-service & $32.8 \%$ & $67.2 \%$ \\
\hline & Pre-service 1 & $8.4 \%$ & $91.6 \%$ \\
\hline & Pre-service 2 & $42.0 \%$ & $58.0 \%$ \\
\hline \multirow{3}{*}{$\begin{array}{l}\text { I assign different homework tasks to } \\
\text { students of differing ability levels }\end{array}$} & In-service & $43.4 \%$ & $56.6 \%$ \\
\hline & Pre-service 1 & $41.7 \%$ & $58.3 \%$ \\
\hline & Pre-service 2 & $68 \%$ & $32.0 \%$ \\
\hline \multirow{3}{*}{$\begin{array}{l}\text { I provide planned or structured individual } \\
\text { (one-to-one) instruction that is embedded } \\
\text { into whole-class teaching }\end{array}$} & In-service & $43.9 \%$ & $56.1 \%$ \\
\hline & Pre-service 1 & $37.5 \%$ & $62.5 \%$ \\
\hline & Pre-service 2 & $47.0 \%$ & $53.0 \%$ \\
\hline \multirow{3}{*}{$\begin{array}{l}\text { Within a class group, I organize students } \\
\text { by ability for teaching and learning } \\
\text { activities }\end{array}$} & In-service & $55.0 \%$ & $45.0 \%$ \\
\hline & Pre-service 1 & $45.8 \%$ & $54.2 \%$ \\
\hline & Pre-service 2 & $53.0 \%$ & $47.0 \%$ \\
\hline \multirow{3}{*}{$\begin{array}{l}\text { I assign grades or marks for homework, } \\
\text { assessments or project work on the basis } \\
\text { of differing criteria }\end{array}$} & In-service & $62.8 \%$ & $37.2 \%$ \\
\hline & Pre-service 1 & $30.5 \%$ & $69.5 \%$ \\
\hline & Pre-service 2 & $53.0 \%$ & $47.0 \%$ \\
\hline
\end{tabular}

We identify binary categories of users of differentiated teaching approaches (those who answered 'sometimes' or 'often' to the items and non-users of differentiated teaching approaches (those who answered 'never' or 'rarely'). Using this division, we see that considerable percentage differences can be observed, particularly between the two preservice groups, in relation to certain questions. For example, $91.6 \%$ of respondents intended to have students working in mixed-ability pairs or small groups "sometimes/often", but after their teaching placement, this had reduced to $58 \%$. When considering the question of the provision of different class material or activities to students of different levels, there was a $41.3 \%$ drop between those who responded "sometimes/often" prior to teaching placement, compared to afterwards. In both of these questions, the responses of the In-Service teachers fell somewhere in the middle of 
those of the two Pre-Service cohorts. When responding to "I assign grades or marks for homework, assignments or project work on the basis of differing criteria", there was a decline from $69.5 \%$ saying "sometimes/often" in Pre-Service 1 to $47 \%$ in Pre-Service 2, but in this case, the In-Service teachers were below that again, at $37.2 \%$, suggesting this is non-standard practice in schools.

\section{Usage of ICT resources during mathematics classes}

The next series of questions posed for in-service teachers related to their usage of ICT resources during mathematics classes (Cosgrove et al 2012, 37). The results of these questions when posed to the pre-service groups are given in Table 5.

Table 5. Teachers' use of ICT resources during mathematics classes. Note: Pre-service 1 respondents wrote about the planned usage; Pre-service 2 wrote about their actual usage. (“In-service” $\mathrm{N}=1321$, "Pre-service 1" $\mathrm{N}=25$, "Pre-service 2” $\mathrm{N}=19$.)

\begin{tabular}{|c|c|c|c|c|c|}
\hline & & $\begin{array}{l}\text { Hardly } \\
\text { ever/ } \\
\text { never }\end{array}$ & $\begin{array}{l}\text { About } \\
\text { once } \\
\text { a term }\end{array}$ & $\begin{array}{l}\text { About } \\
\text { once } \\
\text { a month }\end{array}$ & $\begin{array}{l}\text { At least } \\
\text { once } \\
\text { a week }\end{array}$ \\
\hline \multirow{3}{*}{ Pc or laptop } & In-service & $12.4 \%$ & $8.2 \%$ & $17.1 \%$ & $62.3 \%$ \\
\hline & Pre-service 1 & $0.0 \%$ & $0.0 \%$ & $20.8 \%$ & $79.0 \%$ \\
\hline & Pre-service 2 & $5.3 \%$ & $0.0 \%$ & $15.8 \%$ & $78.9 \%$ \\
\hline \multirow{3}{*}{ Data projector } & In-service & $15.4 \%$ & $8.5 \%$ & $16.1 \%$ & $60.0 \%$ \\
\hline & Pre-service 1 & $0.0 \%$ & $0.0 \%$ & $16.7 \%$ & $83.3 \%$ \\
\hline & Pre-service 2 & $10.5 \%$ & $0.0 \%$ & $15.8 \%$ & $73.9 \%$ \\
\hline \multirow{3}{*}{ Internet sites } & In-service & $16.7 \%$ & $15.1 \%$ & $28.5 \%$ & $39.7 \%$ \\
\hline & Pre-service 1 & $0.0 \%$ & $0.0 \%$ & $33.3 \%$ & $66.7 \%$ \\
\hline & Pre-service 2 & $5.3 \%$ & $5.3 \%$ & $31.6 \%$ & $57.9 \%$ \\
\hline \multirow{3}{*}{$\begin{array}{l}\text { General software } \\
\text { (Powerpoint, Word } \\
\text { etc) }\end{array}$} & In-service & $26.4 \%$ & $15.0 \%$ & $21.4 \%$ & $37.2 \%$ \\
\hline & Pre-service 1 & $4.2 \%$ & $12.5 \%$ & $33.3 \%$ & $50.0 \%$ \\
\hline & Pre-service 2 & $5.3 \%$ & $10.5 \%$ & $21.1 \%$ & $63.2 \%$ \\
\hline \multirow{3}{*}{$\begin{array}{l}\text { Mathematics- } \\
\text { specific software } \\
\text { (Geometer's } \\
\text { Sketchpad, } \\
\text { Geogebra, Logo etc) }\end{array}$} & In-service & $25.3 \%$ & $21.4 \%$ & $28.3 \%$ & $25.0 \%$ \\
\hline & Pre-service 1 & $4.2 \%$ & $12.5 \%$ & $45.8 \%$ & $37.5 \%$ \\
\hline & Pre-service 2 & $5.3 \%$ & $5.3 \%$ & $42.1 \%$ & $47.4 \%$ \\
\hline \multirow{3}{*}{$\begin{array}{l}\text { Spreadsheets } \\
\text { (Excel etc) }\end{array}$} & In-service & $48.9 \%$ & $24.5 \%$ & $19.1 \%$ & $7.5 \%$ \\
\hline & Pre-service 1 & $16.7 \%$ & $29.2 \%$ & $37.5 \%$ & $16.7 \%$ \\
\hline & Pre-service 2 & $21.1 \%$ & $26.3 \%$ & $36.8 \%$ & $15.8 \%$ \\
\hline
\end{tabular}

It should be noted that pre-service teachers were asked about their planned usage of ICT 
resources before their teaching placement, but their actual usage after their placement.

As is the case with the in-service teachers, usage of spreadsheets is uniformly low, although this could have been as a result of the topics assigned to the pre-service teachers during their placements. This is reflected in a comment by one of the preservice teachers who observed "Excel not used that much as most topics do not require it." Usage of PC/laptop, data projector, internet sites and general software is reported as being above $50 \%$ using these at least once a week in each of the pre-service groups, with the first two of these closer to $80 \%$.

In order to better understand the teachers' responses, Cosgrove et al $(2012,37)$ assigned a ranking to each respondent, based on their answers to each of the six above questions. Teachers who reported using at least four of the above resources at least once a week were categorised as high users of ICT; those who never or hardly ever used at least four of the above resources were low users of ICT; the remaining respondents were medium users of ICT. We have used this same ranking system for our respondents and the results are presented in Figure 1 below. We recall that in the pre-service teacher survey, the students were asked to comment on their responses to this question, allowing the following observations. 


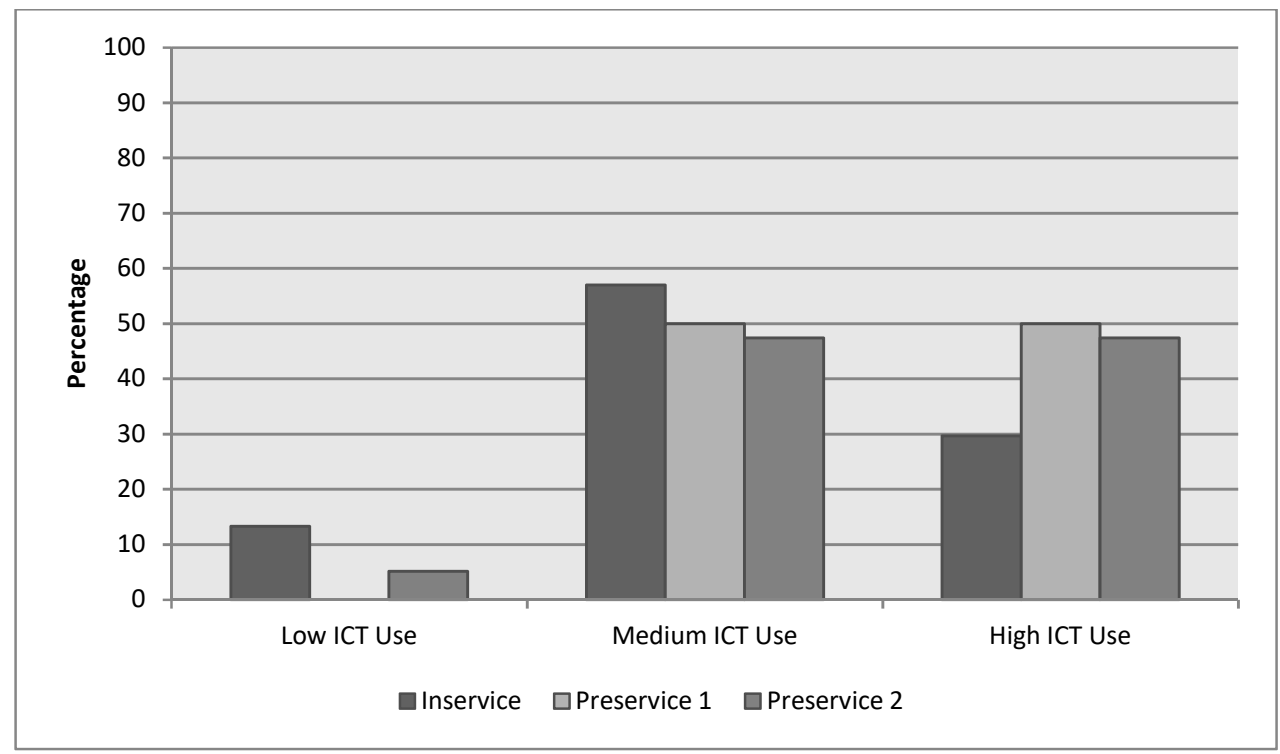

Figure 1. Percentages of low, medium and high users of ICT during mathematics classes: In-service teachers, pre-service teachers before their long teaching placement (Pre-service 1), pre-service teachers after their long teaching placement (Pre-service 2)

Some pre-service teachers directly referred to the equipment available to them while on teaching placement when responding, with some observing how it positively influenced them to use ICT ("Smart board in class which was used in nearly every class...It was a very valuable resource”), while others stated that lack of equipment impacted upon their usage ("I wanted to use a projector to write the sums on and project them on the board but my room was not suitable.")

The pre-service teachers in this cohort would generally be considered to be “digital natives" born into a digital world (Prensky 2001). This is one possible reason underlying the higher intended and reported usage of ICT in the classroom by both cohorts of pre-service teachers as compared with in-service teachers (see Table 5). Nevertheless, it is somewhat surprising that, prior to their teaching placement, only $50 \%$ intended to make a high use of ICT during mathematics classes (before any issues such as access to technology could have come into play in their responses). In fact, this echoes findings by other researchers. Lei (2009) reports that pre-service teachers in a large US university have strong positive beliefs about technology (including beliefs 
relevant to technology in teaching), yet have reserved attitudes to using technology in the classroom. Further, the technological expertise of these digital natives is of limited relevance to the classroom. Much experience and use relates to common social media products, rather than (for example) blogs and wikis. Russell et al (2003) mention that as the early years of teaching are so challenging, there is little time for teachers to spend finding ways to use the available technology. One pre-service teacher explicitly stated that "I used it when I could, when it suited but I definitely didn't go out of my way to try and force it in, I didn't think that would be right to do", an opinion which strongly reflects the observation by Zbiek, Heid and Blume (2007) that teachers' willingness to use various forms of technology "centre around how the teacher's practice and the nature of that technology align” (1187). Indeed, Philipp (2007) reflected that "even when teachers are comfortable using computers or calculators for their own learning, they may not believe that using technology with their students is appropriate” (294). One pre-service teacher went even further than this, expressing the view that ICT usage was not needed for more capable pupils: "I had very little need for use of ICT, as I had a fairly high-ability class who had no trouble paying attention to my teaching." Despite this, it should be noted that only one pre-service teacher fell into the "low ICT use" category, so almost all the pre-service cohort made considerable use of some ICT during their placement.

\section{Confidence levels in teaching aspects of Project Maths}

In-service teachers were also asked about their confidence levels in teaching various aspects of Project Maths (Cosgrove et al 2012, 52). We omitted a single question from the original list ("preparing students for the revised Junior Certificate mathematics examination") as it was felt that pre-service teachers were not in a position to answer this yet. The results of the remaining 13 questions are presented in Table 6 . 
Table 6. Levels of confidence in teaching 13 aspects of Project Maths. Note: in-service teachers answered in relation to Junior Cycle students only. ("In-service" $\mathrm{N}=1321$, “Pre-service 1" $\mathrm{N}=25$, “Pre-service 2" $\mathrm{N}=19$.)

\begin{tabular}{|c|c|c|c|c|c|}
\hline & & $\begin{array}{l}\text { Not at all } \\
\text { confident }\end{array}$ & $\begin{array}{l}\text { Not too } \\
\text { confident }\end{array}$ & $\begin{array}{c}\text { Moderately } \\
\text { confident }\end{array}$ & $\begin{array}{c}\text { Very } \\
\text { confident }\end{array}$ \\
\hline \multirow[t]{3}{*}{ Teaching statistics } & In-service & $0.8 \%$ & $4.0 \%$ & $39.1 \%$ & $56.1 \%$ \\
\hline & Pre-service 1 & $12.5 \%$ & $16.7 \%$ & $58.3 \%$ & $12.5 \%$ \\
\hline & Pre-service 2 & $10.5 \%$ & $21.1 \%$ & $52.6 \%$ & $15.8 \%$ \\
\hline \multirow{3}{*}{$\begin{array}{l}\text { Teaching geometry and } \\
\text { trigonometry }\end{array}$} & In-service & $0.6 \%$ & $6.7 \%$ & $41.8 \%$ & $50.9 \%$ \\
\hline & Pre-service 1 & $0 \%$ & $4.2 \%$ & $54.2 \%$ & $41.7 \%$ \\
\hline & Pre-service 2 & $0 \%$ & $15.8 \%$ & $21.2 \%$ & $63.2 \%$ \\
\hline \multirow[t]{3}{*}{ Teaching probability } & In-service & $1.5 \%$ & $7.4 \%$ & $41.4 \%$ & $49.7 \%$ \\
\hline & Pre-service 1 & $4.2 \%$ & $20.8 \%$ & $37.5 \%$ & $37.5 \%$ \\
\hline & Pre-service 2 & $0 \%$ & $10.5 \%$ & $63.2 \%$ & $26.3 \%$ \\
\hline \multirow{3}{*}{$\begin{array}{l}\text { Providing feedback to } \\
\text { students about their } \\
\text { performance }\end{array}$} & In-service & $0.8 \%$ & $7.3 \%$ & $55.9 \%$ & $35.9 \%$ \\
\hline & Pre-service 1 & $4.2 \%$ & $16.7 \%$ & $50.0 \%$ & $29.2 \%$ \\
\hline & Pre-service 2 & $0 \%$ & $10.5 \%$ & $52.6 \%$ & $36.8 \%$ \\
\hline \multirow{3}{*}{$\begin{array}{l}\text { Teaching students to } \\
\text { solve problems in } \\
\text { real-life settings }\end{array}$} & In-service & $1.2 \%$ & $6.9 \%$ & $59.1 \%$ & $32.9 \%$ \\
\hline & Pre-service 1 & $0 \%$ & $29.2 \%$ & $45.8 \%$ & $25.0 \%$ \\
\hline & Pre-service 2 & $0 \%$ & $15.8 \%$ & $52.6 \%$ & $31.6 \%$ \\
\hline \multirow{3}{*}{$\begin{array}{l}\text { Engaging students in } \\
\text { practical mathematics } \\
\text { activities }\end{array}$} & In-service & $0.8 \%$ & $11.0 \%$ & $56.4 \%$ & $31.7 \%$ \\
\hline & Pre-service 1 & $4.2 \%$ & $33.3 \%$ & $37.5 \%$ & $25.0 \%$ \\
\hline & Pre-service 2 & $0 \%$ & $26.3 \%$ & $52.6 \%$ & $21.1 \%$ \\
\hline \multirow{3}{*}{$\begin{array}{l}\text { Assessing how students } \\
\text { are performing in } \\
\text { mathematics }\end{array}$} & In-service & $2.2 \%$ & $12.7 \%$ & $54.8 \%$ & $30.3 \%$ \\
\hline & Pre-service 1 & $0 \%$ & $16.7 \%$ & $58.3 \%$ & $25.0 \%$ \\
\hline & Pre-service 2 & $0 \%$ & $10.5 \%$ & $42.1 \%$ & $47.4 \%$ \\
\hline \multirow{3}{*}{$\begin{array}{l}\text { Catering for students of } \\
\text { varying mathematical } \\
\text { ability }\end{array}$} & In-service & $1.5 \%$ & $15.1 \%$ & $59.0 \%$ & $24.4 \%$ \\
\hline & Pre-service 1 & $8.3 \%$ & $41.7 \%$ & $37.5 \%$ & $12.5 \%$ \\
\hline & Pre-service 2 & $10.5 \%$ & $36.8 \%$ & $47.4 \%$ & $5.3 \%$ \\
\hline \multirow{3}{*}{$\begin{array}{l}\text { Organising classes so } \\
\text { that students can use } \\
\text { concrete materials }\end{array}$} & In-service & $2.1 \%$ & $18.2 \%$ & $55.9 \%$ & $23.8 \%$ \\
\hline & Pre-service 1 & $0 \%$ & $37.5 \%$ & $58.3 \%$ & $4.2 \%$ \\
\hline & Pre-service 2 & $0 \%$ & $26.3 \%$ & $68.4 \%$ & $5.3 \%$ \\
\hline \multirow{3}{*}{$\begin{array}{l}\text { Supporting students } \\
\text { with learning } \\
\text { difficulties in maths }\end{array}$} & In-service & $2.6 \%$ & $21.3 \%$ & $54.6 \%$ & $21.5 \%$ \\
\hline & Pre-service 1 & $12.5 \%$ & $58.3 \%$ & $20.8 \%$ & $4.2 \%$ \\
\hline & Pre-service 2 & $15.8 \%$ & $15.8 \%$ & $68.4 \%$ & $0.0 \%$ \\
\hline \multirow{3}{*}{$\begin{array}{l}\text { Facilitating students' } \\
\text { independence in } \\
\text { problem solving/doing } \\
\text { mathematics }\end{array}$} & In-service & $1.9 \%$ & $16.7 \%$ & $61.0 \%$ & $20.4 \%$ \\
\hline & Pre-service 1 & $12.5 \%$ & $41.7 \%$ & $37.5 \%$ & $8.3 \%$ \\
\hline & Pre-service 2 & $0 \%$ & $31.6 \%$ & $57.9 \%$ & $10.5 \%$ \\
\hline \multirow{3}{*}{$\begin{array}{l}\text { Analysing students' } \\
\text { problem-solving } \\
\text { strategies }\end{array}$} & In-service & $1.9 \%$ & $21.5 \%$ & $58.8 \%$ & $17.8 \%$ \\
\hline & Pre-service 1 & $20.8 \%$ & $41.7 \%$ & $33.3 \%$ & $4.2 \%$ \\
\hline & Pre-service 2 & $5.3 \%$ & $26.3 \%$ & $52.6 \%$ & $15.8 \%$ \\
\hline \multirow{3}{*}{$\begin{array}{l}\text { Engaging students in } \\
\text { assessing their own } \\
\text { progress/performance } \\
\text { in maths }\end{array}$} & In-service & $2.4 \%$ & $27.4 \%$ & $53.4 \%$ & $16.8 \%$ \\
\hline & Pre-service 1 & $16.7 \%$ & $41.7 \%$ & $41.7 \%$ & $0.0 \%$ \\
\hline & Pre-service 2 & $5.3 \%$ & $42.1 \%$ & $47.4 \%$ & $5.3 \%$ \\
\hline
\end{tabular}


There is a clear trend of students reporting lower levels of confidence prior to their teaching placement. For example, when asked about supporting students with learning difficulties in mathematics, only $25 \%$ of Pre-Service 1 students were "moderately confident" or "very confident"; this rose to $68.4 \%$ in the Pre-Service 2 cohort. Similarly, their confidence rose when dealing with analysing students' problem-solving strategies, with $37.5 \%$ of Pre-Service 1 students "moderately confident" or "very confident”, compared with $68.4 \%$ of Pre-Service 2 . Fewer in-service teachers express low or no confidence in teaching these aspects of Project Maths, almost without exception.

\section{Perceived challenges in implementation of Project Maths}

Finally, in-service teachers were asked about the perceived challenges in the implementation of Project Maths (Cosgrove et al 2012, 54). A number of these statements, relating to parental or student reaction, for example, were not applicable to the pre-service cohort, so only five out of the twelve original statements were put to this group. The results are shown in Table 7. 
Table 7. Perceived challenges in the implementation of Project Maths. ("In-service" $N=$ 1321, "Pre-service 1" $\mathrm{N}=25$, "Pre-service 2" $\mathrm{N}=19$.)

\begin{tabular}{|l|l|r|r|r|}
\hline & & $\begin{array}{c}\text { Not a } \\
\text { challenge }\end{array}$ & $\begin{array}{c}\text { A } \\
\text { challenge }\end{array}$ & $\begin{array}{c}\text { A major } \\
\text { challenge }\end{array}$ \\
\hline \multirow{2}{*}{$\begin{array}{l}\text { Time, e.g. to be familiar with } \\
\text { coursework, to prepare classes, } \\
\text { group work and investigations }\end{array}$} & In-service & $3.4 \%$ & $36.7 \%$ & $59.8 \%$ \\
\cline { 2 - 5 } & Pre-service 1 & $4.0 \%$ & $28.0 \%$ & $68.0 \%$ \\
\cline { 2 - 5 } & Pre-service 2 & $11.1 \%$ & $38.9 \%$ & $50.0 \%$ \\
\hline \multirow{2}{*}{$\begin{array}{l}\text { Literacy demands of the new } \\
\text { courses }\end{array}$} & In-service & $14.2 \%$ & $36.1 \%$ & $49.7 \%$ \\
\cline { 2 - 5 } & Pre-service 1 & $8.0 \%$ & $28.0 \%$ & $64.0 \%$ \\
\cline { 2 - 5 } & Pre-service 2 & $5.6 \%$ & $44.4 \%$ & $50.0 \%$ \\
\hline \multirow{2}{*}{$\begin{array}{l}\text { The rate of implementation of } \\
\text { Project Maths }\end{array}$} & In-service & $12.5 \%$ & $44.7 \%$ & $42.8 \%$ \\
\cline { 2 - 5 } & Pre-service 1 & $28.0 \%$ & $64.0 \%$ & $8.0 \%$ \\
\cline { 2 - 5 } & Pre-service 2 & $11.1 \%$ & $66.7 \%$ & $22.2 \%$ \\
\hline \multirow{2}{*}{$\begin{array}{l}\text { Assessment materials, e.g. sample } \\
\text { examination papers and guidelines } \\
\text { on assessing students' progress }\end{array}$} & In-service & $18.6 \%$ & $39.7 \%$ & $41.7 \%$ \\
\cline { 2 - 5 } & Pre-service 1 & $12.0 \%$ & $68.0 \%$ & $20.0 \%$ \\
\cline { 2 - 5 } $\begin{array}{l}\text { Teaching materials e.g. the content } \\
\text { and range of textbooks available }\end{array}$ & Pre-service 2 & $27.8 \%$ & $50.0 \%$ & $22.2 \%$ \\
\cline { 2 - 5 } & In-service & $22.6 \%$ & $45.8 \%$ & $31.6 \%$ \\
\cline { 2 - 5 } & Pre-service 1 & $44.0 \%$ & $44.0 \%$ & $12.0 \%$ \\
\cline { 2 - 5 } & Pre-service 2 & $38.9 \%$ & $27.8 \%$ & $33.3 \%$ \\
\hline
\end{tabular}

There is an apparent difference between the percentages of pre-service teachers who ranked the "rate of implementation of Project Maths" as a major challenge before and after teaching placement, with only $8 \%$ from the first cohort and $22.2 \%$ from the second cohort ranking it as such. Similarly, in terms of "teaching materials", 12\% found this a major challenge before placement, compared with $33.3 \%$ afterwards. .

Respondents were given the opportunity to list "other" challenges they experienced. On this issue, the pre-service teachers' comments mirrored those given by in-service teachers (Cosgrove et al 2012, 58-64), with references to the challenges listed above, as well as three other themes identified by Cosgrove et al, namely lack of resources, change, and methodology. When asked to comment in more detail about the challenges they perceived in relation to Project Maths, pre-service teachers firstly focused on the limited time available ("Actually getting through the content in the class. I feel that when using project maths it is all too rushed."). Tate (2007) noted the 
importance of "sufficient and appropriate time to learn the mathematics curriculum", reflecting the challenge identified here. Pre-service teachers commented briefly on the high literacy demands ("It is a problem for students with dyslexia"), the rate of implementation of Project Maths ("Students who maybe did Transition Year who did not do Project Maths for Junior Cert and now are completely lost in Leaving Cert maths"), assessment materials ("The final exams I don't feel reflect the aims of the curriculum") and teaching materials ("I also found it hard to get the worksheets or project ideas that suited best.”).

As mentioned above, three additional challenges were identified by pre-service teachers, all of which mirrored themes from Cosgrove et al (2012). The first of these was a simple lack of resources. Although this had emerged during the comments made about ICT usage, pre-service teachers now spoke of an absence of more basic resources ("When using the algebra tiles..., there were not even tiles for every group"). Similarly, the in-service teachers in Cosgrove et al (2012) noted concerns about funds available to buy resources. Another challenge identified by pre-service teachers was change - both for the in-service teachers and for the students. One comment made under this theme ("Whilst on my placement I noticed that teachers are not adapting to the project maths style of learning at all. Teachers are continuing to teach maths in the traditional way and then expect students to be able to complete a very different style exam paper.”) closely echoes the findings of Jeffes et al (2013) that "there does not appear to have been a substantial shift in what teachers are asking students to do...traditional approaches to mathematics teaching and learning continue to be widespread" (4). In relation to the challenge presented for students, one teacher commented that "A problem I had...was that students were too used to being handed formulas and being told step by step what has been done and it's very hard to get out of that habit and then students get 
frustrated and begin to dislike maths". Again, this is reflected in Jeffes et al (2013), who found that, when compared with others who participated in TIMSS 2007, students following the revised syllabuses were "slightly less positive about mathematics". The final challenge listed by pre-service teachers was methodology. Some such comments reflected the difficulty of maintaining a "new" way of teaching ("I always turn back to the old way when I felt the students were lost as I felt I was wasting time"), an observation that is in line with previous research in this area, with Sowder (2007) stating that "the job demands are intense when teachers begin teaching, so to find that new teachers often fall back on practices they know best is not surprising." Other comments under this theme concerned an overall disagreement with the emphasis within Project Maths ("I feel the amount of expected student involvement in conceptlearning experimentation has TOO much emphasis within the curriculum, which places a huge restraint on time spent teaching the theory of the concepts, and practicing the exercises/examples, which is still, in my opinion, the most important part of maths teaching”). This was in line with some of the comments made by in-service teachers under the same theme.

\section{Discussion and Conclusions}

Perhaps the most striking result of the survey is the overall similarity of the opinions of the pre-service and in-service teachers. Behind this overall similarity, some differences do emerge. As noted above, the pre-service teachers use ICT more heavily (Figure 1). They more frequently report that mathematics is a difficult subject for most students (Table 1). Pre-service teachers make less use of whole-class teaching activities, and more use of group-learning activities than their in-service colleagues (Table 3).

Likewise, differences in the opinions held by the pre-service teachers before and after their placement are difficult to discern, but some are evident. For example, the pre- 
service teachers report that they are less inclined to assign marks by different criteria (Table 4) after placement than they were before placement. It is perhaps noteworthy that across this theme (Use of Differentiated Teaching Techniques), there is a reported move away from every such technique surveyed by the end of the placement period. Interestingly, in relation to three questions in this category, the pre-service teachers' opinions move towards those of the in-service teachers, while the opposite occurs with the other three: the pre-service teachers held opinions closer to those of the in-service teachers before the school placement period. Under the Classroom Activity domain, pre-service teachers report less emphasis on Assessment and Administrative Tasks after placement than before. In relation to Confidence Levels in Teaching Aspects of Project Maths (Table 6),again it is noteworthy that across 11 of the 13 individual items in this category, a change is discernible that corresponds to a gain in confidence among the pre-service teachers. In conclusion, and to reflect on the findings of Gleeson et al (2014) and of Cherubini (2009), we find little evidence that there is a significant influence of school culture(s) exerted either by in-service teachers or the school system generally that absorbs pre-service teachers into a distinct set of opinions and teaching practices characteristic of those in-service teachers.

As noted, overall we have found little difference in terms of the opinions expressed in the survey between pre-service and in-service teachers. In particular, preservice teachers struggle with many of the same methodological, technological and curriculum-related issues as in-service teachers; most notably literacy and use of tools/resources in delivering Project Maths. This reinforces the findings of Cosgrove et al (2012), in the case of this cohort of pre-service teachers.

Pre-service teachers in this cohort display quite traditional teaching approaches, both pre- and post-placement, which appears to be reinforced by the largely traditional 
approaches established by Cosgrove et al (2012) to be the norm in schools. In particular, this approach to teaching mathematics was the norm when our pre-service teachers were themselves learning mathematics at second level. The positive benefits of a school placement period are evident in our results in that they show that experience teaching Project Maths leads to higher confidence levels with teaching Project Maths. Raising confidence in teaching and in carrying out other aspects of the teacher's role is central to the purpose of the school placement element of teacher education programmes - see e.g. Teaching Council (2011) for a locally relevant expression of this. Teachers need lots of experiences, support and collegial interaction while working through the content and pedagogy of Project Maths, and this may be especially true for preservice teachers who are being asked to make a transition from a fairly traditional maths learning experience in school (Lyons et al. 2003) to a more student-centred approach as teachers. Our study has highlighted this issue, albeit for a small cohort of students. These low numbers notwithstanding, it is important to identify this issue which is of particular relevance to us as teacher educators, and to others involved in teacher education at a time of transition.

We have compared and contrasted the opinions held by the three different cohorts considered in this study. However, considering the opinions of the pre-service teachers in isolation is also worthwhile. Here, there is evidence that a high number of these teachers do not value or practice the kind of connectivist, student-centred teaching approaches mandated by Project Maths (see Tables 3 and 4). This emphasises the need for a continued focus in teacher preparation programmes on how to be true to Project Maths content and methodology in a school system that maintains largely traditional cultures and approaches to teaching and learning mathematics. 
Teachers throughout Ireland, both in-service and pre-service, still need support in adjusting to the content and methodology of Project Maths. Cosgrave et al. (2012) include in their recommendations the provision of particular elements of CPD (including a focus on mathematics teaching methods, assessment, mathematical literacy and enhancing contexts of mathematics), and the need for in-service teachers to identify gaps in their professional development. In a separate study, Guerrero (2014) identifies the need for effectively-led school-level supports to be put in place. These must enable collaboration and communication between teachers at the local level. Lesson study has been espoused as a means of enacting such a process in the Irish context (Ní Shuilleabháin 2014).

Finally, we note that the work reported here shows that pre-service teachers still have fundamental, deeply-rooted concerns about the content and methodology of Project Maths. This is particularly evident in the comments provided by the respondents. This indicates a need for providers of programmes of initial teacher education in Ireland to continually address these concerns, especially when the field experiences of the pre-service teachers are more traditional than the methodology espoused by their programme.

Acknowledgements: The third author would like to acknowledge that financial support was provided by CAPES (Coordenação de Aperfeiçoamento de Pessoal de Nível Superior), Brazil.

\section{References}

Adler, J. 2000. Conceptualising resources as a theme for teacher education. Journal of Mathematics Teacher Education, 3(3), 205-224.

AFT (American Federation of Teachers). 2002. Principles for professional development. Washington, DC: Author. 
Allen, J. 2009. Valuing practice over theory: how beginning teachers re-orient their practice in the transition from the university to the workplace. Teaching and Teacher Education, 25(5), 647-654.

Bean, T.W. and Patel Stevens, L. 2002. Scaffolding reflection for pre-service and inservice teachers. Reflective Practice: International and Multidisciplinary Perspectives, 3(2), 205-218.

Bjerke, A. H., Eriksen, E., Rodal, C., Smestad, B., \& Solomon, Y. 2013. Theorising mathematics teaching: pre-service teachers' perceptions before and during school placement. In: Pareliussen, I.,Moen, B.B., Reinertsen A., Solhaug, T.: FoU i praksis 2012 conference proceedings, Akademika forlag Trondheim, pp. 20-27.

Bos, C., Mather, N., Dickson, S., Podhajski, B. and Chard, D. 2001. Perceptions and knowledge of pre-service and in-service educators about early reading instruction. Annals of Dyslexia, 51, 97 - 120.

Bullock, D. 2004. Moving from theory to practice: An examination of the factors that pre-service teachers encounter as they attempt to gain experience teaching with technology during field placement experiences. Journal of Technology and Teacher Education, 12(2), 211-237.

CAO (Central Applications Office). 2014. CAO Handbook 2014. Galway: Central Applications Office. http://www2.cao.ie/handbook/handbook/hb.pdf

Cherubini, L. 2009. Reconciling the tensions of new teachers' socialisation into school culture: A review of the research. Issues in Educational Research, 19, 83-99.

Conway, P.F. and Sloane, F.C. 2005. International trends in post-primary mathematics education: perspectives on learning, teaching and assessment. Dublin: NCCA.

Cosgrove, J., Perkins, R., Shiel, G., Fish, R. and McGuinness, L. 2012. Teaching and learning in Project Maths: Insights from teachers who participated in PISA 2012. Dublin: Educational Research Centre.

DES (Department of Education and Skills). 2004. A brief description of the Irish education system. Dublin, Ireland: Department of Education and Skills. http://www.education.ie/en/Publications/Education-Reports/A-BriefDescription-of-the-Irish-Education-System.pdf

DES (Department of Education and Skills). 2015. Curriculum and Syllabus. https://www.education.ie/en/Schools-Colleges/Information/Curriculum-and$\underline{\text { Syllabus/ }}$ 
Ensor, P. 2001. Pre-service mathematics teacher education to beginning teaching: a study in recontextualising. Journal for Research in Mathematics Education, 32(3), 296-320.

Gleeson, J., O’Flaherty, J., Galvin, T. and Hennessy, J. 2015. Student teachers, socialisation, school placement and schizophrenia: the case of curriculum change, Teachers and Teaching, 21:4, 437-458

Guerrero, S. 2014. Teacher change and Project Maths: implications and lessons learned. Bulletin of the Irish Mathematical Society, 74, 27-66.

Jeffes, J., Jones, E., Wilson, M., Lamont, E., Straw, S., Wheater, R. and Dawson, A. 2013. Research into the impact of Project Maths on student achievement, learning and motivation: final report. Slough: NFER.

Lei, J. 2009. Digital Natives As Preservice Teachers, Journal of Computing in Teacher Education, 25:3, 87-97

Lubienski, S. 2011. Mathematics education and reform in Ireland: an outsider's analysis of Project Maths. Irish Mathematical Society Bulletin, 67, 27-55.

Lyons, M., Lynch, K., Close, S., Sheerin, E., and Boland, P. (2003). Inside classrooms: The teaching and learning of mathematics in social context. Dublin: Institute of Public Administration.

Murphy, P.K., Delli, L.A.M. and Edwards, M.N. 2004. The good teacher and good teaching: comparing beliefs of second-grade students, pre-service teachers, and in-service teachers. The Journal of Experimental Education, 72(2), 69-92.

NCCA (National Council for Curriculum and Assessment). 2005. Review of mathematics in post-primary education: a discussion paper. http://www.ncca.ie/uploadedfiles/MathsReview/MathsDiscusPaperEng.pdf

NCCA (National Council for Curriculum and Assessment). 2012. Project Maths. Responding to Current Debate. http://ncca.ie/en/file/post_primary/response.pdf

Ng, W., Nicholas, H. and Williams, A. 2010. School experience influences on preservice teachers' evolving beliefs about effective teaching. Teaching and Teacher Education, 26(2), 278-289.

Ni Shuilleabhain, A. (2014). Lesson study and Project Maths: A Professional Development Intervention for Mathematics Teachers Engaging in a New Curriculum. In S. Pope (Ed.), 8th British Congress of Mathematics Education (pp. 255-262). Nottingham University. 
O'Rourke, N., Psych, R. and Hatcher, L., 2013. A step-by-step approach to using SAS for factor analysis and structural equation modeling. Sas Institute.

Philipp, R.A. 2007. Mathematics teachers' beliefs and affect. In F.K. Lester, Jr. (Ed.), Second Handbook of Research on Mathematics Teaching and Learning, (157224). Charlotte: Information Age Publishing Inc.

Prendergast, M., Faulkner, F., Breen, C. and Carr, M., 2017. Mind the gap: an initial analysis of the transition of a second level curriculum reform to higher education. Teaching Mathematics and its Applications: An International Journal of the IMA, p.hrw024.

Prendergast, M. and O'Meara, N., 2017. A profile of mathematics instruction time in Irish second level schools. Irish Educational Studies, 36(2), pp.133-150.

Prensky, M. 2001. Digital natives, digital immigrants. On the Horizon, 9(5), 1-6.

Russell, M., Bebell, D., O’Dwyer, L. and O’Connor, K. 2003. Examining teacher technology use: implications for pre-service and in-service teacher preparation. Journal of Teacher Education, 54(4), 297-310.

Shiel, G. and Kelleher, C., 2017. An Evaluation of the Impact of Project Maths on the Performance of Students in Junior Cycle Mathematics. Dublin, Ireland: Education Research Centre. http://www.juniorcycle.ie/NCCA JuniorCycle/media/NCCA/Documents/Curric ulum/Maths/PM_EvaluationStrand1.pdf

Shim, M.K., Young, B.J. and Paolucci, J. 2010. Elementary teachers' views on the nature of scientific knowledge: A comparison of in-service and pre-service teachers approach. Electronic Journal of Science Education, 14:1.

Smyth E. 2016. Teaching, Learning and Assessment. In: Students' Experiences and Perspectives on Secondary Education. Palgrave Macmillan, London

Sowder, J.T. 2007. The mathematical education and development of teachers. In F.K. Lester, Jr. (Ed.), Second Handbook of Research on Mathematics Teaching and Learning, (157-224). Charlotte: Information Age Publishing Inc.

Steele, D.F. 2001. The interfacing of pre-service and in-service experiences of reformbased teaching: a longitudinal study. Journal of Mathematics Teacher Education, 4, 139-172.

Sullivan-Watts, B.K., Nowicki, B.L., Shim, M.K. and Young, B.J. 2013. Sustaining reform-based science teaching of pre-service and in-service elementary school teachers. Journal of Science Teacher Education, 24, 879-905. 
Swars, S., Hart, L. C., Smith, S. Z., Smith, M. E. and Tolar, T. 2007. A longitudinal study of elementary pre-service teachers' mathematics beliefs and content knowledge. School Science and Mathematics, 107, 325-335

Tate, W.F. 2007. Engineering change in mathematics education: research, policy and practice. In F.K. Lester, Jr. (Ed.), Second Handbook of Research on Mathematics Teaching and Learning, (1209-1246). Charlotte: Information Age Publishing Inc.

Teaching Council 2011. Initial Teacher Education: Criteria and Guidelines for Programme Providers. Maynooth: The Teaching Council. http://www.teachingcouncil.ie/en/Publications/Teacher-Education/InitialTeacher-Education-Criteria-and-Guidelines-for-Programme-Providers.pdf

Treacy, P. and Faulkner, F., 2015. Trends in basic mathematical competencies of beginning undergraduates in Ireland, 2003-2013. International Journal of Mathematical Education in Science and Technology, 46(8), pp.1182-1196.

Zbiek, R.M., Heid, M.K. and Blume, G.W. 2007. Research on technology in mathematics education. In F.K. Lester, Jr. (Ed.), Second Handbook of Research on Mathematics Teaching and Learning, (157-224). Charlotte: Information Age Publishing Inc. 